\title{
Dociekania
}

\section{Ponadpłciowa solidarność (?). Wsparcie mężczyzn w walce o prawa wyborcze Polek}

Maciej Duda

TEKSTY DRUGIE 2019, NR 3, S. 187-207

DOI: 10.18318/td.2019.3.12 | ORCID: 0000-0001-6864-2446

\section{Kilka uwag natury metodologicznej}

Historyczna opowieść o mężczyznach wspierających emancypację Polek niesie możliwość skomplikowania polskich badań herstorycznych. Badania ich pism oraz działalności traktuję jako pracę z pogranicza historii ujmowanej bezprzymiotnikowo, historii kobiet oraz historii kreślonej w perspektywie płci i rozdzielnie traktowanej perspektywie rodzaju'. Jest to odruch przepisywania historii kultury, któremu towarzyszą następujące cele. Pierwszy to uzupełnienie informacji na temat działań ruchów emancypacyjnych o szczególny, w wymiarze płci, komponent współpracy kobiet z mężczyznami czy mężczyzn z kobietami. Drugi to komplikacja dotychczasowych badań i próba odpowiedzi na pytania o możliwość aktywności i podmiotowości mężczyzn w ramach historycznych ruchów kobiet na rzecz emancypacji oraz o zakres efektów samodzielnych działań kobiet w społecznej

1 Por. M. van Tilburg Historia kobiet czy historia "gender"? Poststrukturalistyczne inspiracje w badaniach nad dziejami płci, przeł. E. Domańska, „Historyka: Studia Metodologiczne" 2000 t. 30, s. 27-37.

Maciej Duda - dr

hab. nauk humanistycznych, psychoterapeuta. Pracownik Akademii im. Jakuba z Paradyża, członek redakcji "Czasu Kultury.".Autor monografii: Polskie Batkany. Proza postjugosłowiańska w kontekście feministycznym, genderowym i postkolonialnym. Recepcja polska (2013), Dogmat płci. Polska Wojna z gender (2016), Emancypanci iemancypatorzy. Mężczyźni wspierający emancypację Polek w drugiej połowieXIX ina początku XX wieku (2017). Stypendysta NCN i MNiSW. Kontakt: mcjduda@ gmail.com 
strukturze, która uniemożliwiała im pełnienie jakiejkolwiek roli publicznej, ograniczała ich podmiotowy i bezpośredni wpływ na kształt polityki rozebranego państwa. Istotnym wskazaniem drugiego celu jest także pytanie o wymuszony, strategiczny sojusz kobiet, organizacji kobiet ze społecznymi aktorami, których prawo i obyczaj wyposażyło w narzędzia normatywizujące życie kobiet i mężczyzn.

Badania mężczyzn wspierających emancypacyjne dążenia kobiet wpisują się zatem w nurt konstruowania historii jako możliwość buntu, historii w wymiarze krytycznym, przeciw-historii ${ }^{2}$. Nienapisana historia mężczyzn - sojuszników emancypacji Polek komplikuje zarówno główny nurt historii, wobec którego praktyka historiograficzna nazywana historią kobiet postrzegana jest jako rewizyjna, jak i sam dyskurs emancypacyjny. Nie oznacza to jednak, że efekt takiej pracy prowadzić ma do przewrotu i zastąpienia skostniałego już nurtu historii, którego twórcy i twórczynie w swoich badaniach nie uwzględniali kontekstu płci społeczno-kulturowej. Wyników prowadzonych badań nie należy także traktować jako suplementu czy w tym wypadku suplementu do suplementu, jak można by przedstawić historię działalności zwolenników emancypacji kobiet w ramach marginalizowanej historii ruchów kobiet. Suplement wiązałby się ze zgodą na uznanie modelu dyskursu o wiedzy historycznej, którego podstawą jest myślenie hierarchiczne, lub ze zgodą na istniejący kontrakt wyznaczający wagę tematów, kontekstów i bohaterów ${ }^{3}$. Zamiast tego skupiam się na krytycznym wymiarze pracy. $\mathrm{Na}$ aspekcie uwzględniającym niezgodę wobec istniejącego porządku społecznego i narracyjnego. Porządku, który tworzą relacje władzy. W ten sposób historia działań i pism badanych przez autorów ma istotny wymiar rewoltujący.

Dotychczas historyczne studia poświęcone literaturze i działalności kobiet, ukazując literackie i światopoglądowe polemiki, naprzeciwko siebie stawiały najczęściej pióra kobiet i mężczyzn. Mogło to wynikać z polaryzacji publicystycznych opinii opartej na kanwie hasła „wojna płci”, które jako hasło krytyczne towarzyszyło przeciwnikom ruchu emancypacyjnego we wskazanym okresie historycznym w całej Europie. Metafora „walka/wojna płci” ukazywała i ukazuje relacje kobiet i mężczyzn w patriarchalnej perspektywie, która zakłada płciową i systemową podległość, podporządkowanie kobiet.

2 Por. M. Solarska S/Przeciw-historia. Wymiar krytyczny historii kobiet, Oficyna Wydawnicza Epigram, Bydgoszcz 2011.

3 Por. E. Domańska Historie niekonwencjonalne. Refleksja o przeszłości w nowej humanistyce, Wydawnictwo Poznańskie, Poznań 2006. 
W jej ramach emancypacyjny i feministyczny zwrot mający doprowadzić do równości praw kobiet i mężczyzn przez tych ostatnich postrzegany jest jako rewolucja lub jako wypowiedzenie wojny nie tylko naturalnemu porządkowi, ale też samym mężczyznom. Jako bunt przeciw danym wzorom, przeciwko esencji i binarnemu porządkowi ${ }^{4}$. Badania historyczne ukazujące rolę mężczyzn w polskich ruchach emancypacyjnych i feministycznych XIX i XX wieku niosą szanse uzupełnienia tej prostej tezy nieznanymi dotąd kontekstami. Zamiast przeciwstawienia ról oraz interesów kobiet i mężczyzn akcentują możliwość ich podmiotowej współpracy, która wykraczała poza społeczne ustalenia kształtujące ówczesne relacje między płciami.

Badania aktywności i podmiotowości mężczyzn w emancypacyjnych działaniach kobiet przynoszą także szereg pytań o pozycję mężczyzny w feministycznych dyskursach. Według Alice Jardine ${ }^{5}$ aktywny feministycznie mężczyzna musi ominąć pułapki własnej ignorancji i praktykę patrzenia z zewnątrz. Do takich praktyk zachęca go patriarchalna dywidenda. Sympatyk i aktywista kobiecych czy feministycznych ruchów emancypacyjnych powinien krytycznie spojrzeć na pozycję, którą zajmuje w społeczeństwie, a jego praca na rzecz równości obejmować powinna badania historycznych konstruktów męskości i seksualności mężczyzn.W ten sposób praktyki spod znaku studiów nad męskościami stają się uzupełnieniem i kontynuacją badań nad kobietami i kobiecościami.

W tym miejscu warto zwrócić uwagę na jeszcze jeden problem. Inny badacz ruchów, David Kahane ${ }^{6}$, wyszczególnił pułapki, w które wpadają współcześni mężczyźni popierający feministyczne działania. W tym kontekście wyróżnił cztery postawy feministów oraz opisał związane z nimi motywacje. Pierwszy typ wiązał się z udawaniem, czyli intelektualnym zainteresowaniem feministyczną teorią, które objawiało się dyskusją z powyższą. Taka dyskusja prowadzona miała być z pozycji, która nie uwzględnia płci, rasy, pochodzenia oraz innych czynników wyznaczających tożsamość interlokutora perorującego na temat feminizmu. Autor nazwał go poseur.

4 M. Duda Wojna płci, w: Encyklopedia gender. Płeć w kulturze, red. M. Rudaś-Grodzka i inne, Czarna Owca, Warszawa 2014, s. 578-580.

5 A. Jardine Men in Feminism: Odor di Uomo Or Compagnons de Route?, w: Men in Feminism, ed. by A. Jardine, P. Smith, [Wydawnictwo], New York 1987. Omówienie za: K. Kłosińska Feministyczna krytyka literacka, Wydawnictwo UŚ, Katowice 2010, s. 634-635.

6 D.J. Kahane Male Feminism as Oxymoron, w: Men Doing Feminism, ed. by T. Digby, Routledge, New York 1998, s. 213-236. 
Druga postawa wiązała się z brakiem wyczucia i autorefleksji, które mimo lektury właściwych książek, poczucia etycznej i politycznej wspólnoty oraz zaangażowania w pracę nie prowadziło do autorefleksji na temat własnego interesu i własnych męskich przywilejów. Ten określony został mianem insider. Insider nie dostrzegał swoich seksistowskich i ugenderowionych tendencyjnych zachowań. Kahane odrzucił także nadmierną autorefleksyjność mężczyzn, którzy feministyczne teorie wykorzystywali tylko do odpowiedzi na pytania, jak patriarchat wypaczał i zniekształcał ich własny obraz, poczucie samych siebie. Mężczyzna, który chciał się uwolnić od stereotypowo pojętej męskości, być innym rodzajem mężczyzny, bardziej wrażliwym i mniej podporządkowanym społecznym strukturom patriarchatu, nosił miano humanisty. Problematyczny był jednak jego brak zainteresowania opresją kobiet oraz współpracą z nimi. Ostatnim typem niepożądanej aktywności był samobiczownik (self-flagellator). Jego analizy skupiały się na własnej winie, co mogłoby być podstawą zmiany. Niestety self-flagellator postrzegał siebie jako bierne narzędzie patriarchatu.

Kolejnym problemem staje się kwestia (auto)określenia mężczyzn wspierających emancypacyjne i feministyczne postulaty. Kimmel i Mosmiller ${ }^{7}$ szukali amerykańskich pro-feministów. Zrezygnowali z użycia określeń feminista (feminist man) i męski feminista (male feminist). We wprowadzeniu do swojej pracy zapewniali, że mężczyzna może wierzyć $\mathrm{w}$ feminizm (believe in feminism). Tę formułę poprzedzili uwagą o empirycznej obserwacji, której wyniki wskazują brak równości między mężczyznami i kobietami w przestrzeni publicznej i prywatnej. Mężczyźni zgadzający się z moralnym założeniem feminizmu, popierają działanie na rzecz równości i sprawiedliwości. W taki sposób scharakteryzowana została wiara w feminizm. Ale, jak pisali badacze, bycie feministą obejmuje także inny warunek: doświadczenie opresji, której nie odczuwają mężczyźni. W przypadku mężczyzn płciową opresję zastępuje przywilej. Mężczyzna czerpie zyski z genderowo ustalonych relacji. Autorzy zapewnili dalej, że każdy mężczyzna także odczuwa/może odczuwać różne rodzaje opresji, nie jest to jednak opresja mężczyzny jako mężczyzny/opresja, której warunkiem jest płeć mężczyzny (opressed as men).

Reasumując, bycie feminist(k)ą wymaga udziału w feministycznej analizie i wizji oraz doświadczenia opresji. Mężczyzna wspierający walkę o równości

7 M.S. Kimmel, T.E. Mosmiller Against the tide. Pro-feminist men in the United States, 1776-1990. A Documentary History, Beacon Press, Boston 1992. 
płci może być określony w dwojaki sposób. Jako anty-seksista lub pro-feminista. Kimmel, chcąc akcentować pozytywne wsparcie walki kobiet, wybrał drugie określenie.

Prowadząc badania polskich mężczyzn wspierających idee i walkę kobiet o równouprawnienie, zrezygnowałem $\mathrm{z}$ anglosaskiego określenia pro-feminiści. Opisywanych mężczyzn nie nazywam także feministami. Zaważyły na tym względy historyczne, nie ideowe. Nazwanie mężczyzn, którzy wspierali grupę Entuzjastek oraz emancypacyjne dążenia kobiet, określeniem feminiści albo pro-feminiści, byłoby historycznym nadużyciem. Wykorzystując powyższą praktykę, można ich określić jako entuzjastów lub pro-entuzjastów, emancypantów lub pro-emancypantów, którzy popierali i wspierali dążenia kobiet do edukacji średniej i wyższej, ich nieograniczoną możliwość pracy zawodowej oraz uzyskanie praw cywilnych równych mężczyznom.

Przy wyborze określenia dla owych mężczyzn najważniejszym dokumentem stał się słownik zbierający słownictwo z epoki, w której działali. W tym wypadku był to Stownik Jezzyka Polskiego Jana Karłowicza, Adama Kryńskiego i Władysława Niedźwiedzkiego. Redaktorzy podali dwie formy określające mężczyzn związanych z kwestią/ruchem emancypacji kobiet. Pierwsza to emancypant, czyli zwolennik emancypacji kobiet. Druga to emancypator, czyli „krzewiciel emancypacji, oswobodziciel. Torował drogę, po której mieli stąpać przyszli emancypatorowie"8. Samą emancypację definiowali jako uwolnienie z zależności, usamowolnienie, równouprawnienie kobiet, niewolników, włościan.

W niniejszym tekście sięgam do obu określeń. Piszę o emancypantach i emancypatorach. Dzięki temu zachowuję historyczną zgodność językową, wskazuję stopień aktywności bohaterów i nie powoduję ideowej kolizji zarysowanej w badaniach anglosaskich.

\section{Wstępny rysopis emancypantów}

W tym miejscu zapytać należy, co oznaczało bycie emancypantem lub emancypatorem. Zwolennik i krzewiciel emancypacji Polek mógł popierać edukację kobiet, możliwość ich pracy zawodowej, możliwość swobodnego zawierania umów, równości w prawach małżeńskich i rodzicielskich, równość

8 Słownik/ęzyka Polskiego, red. J. Karłowicz, A. Kryński, W. Niedźwiedzki, T. I, Warszawa 1900 [reprint, PIW, Warszawa 1952], s. 691. 
w prawach dziedziczenia, wreszcie równość praw w zakresie działalności publicznej, urzędowej i politycznej. Każdy z wymienionych zakresów dyskutowany był osobno. Już sama kwestia edukacji obejmowała takie zagadnienia jak obowiązek nauki dla dziewcząt, udoskonalenie programów nauczania na prywatnych pensjach, organizację szkolnictwa publicznego, nieodpłatnego, zrównanie poziomu edukacji dziewcząt i chłopców, organizację edukacji na poziomie średnim, możliwość podjęcia studiów wyższych przez kobiety oraz możliwość ukończenia ich z dyplomem. Na podstawie tego krótkiego, przykładowego wyliczenia można wyobrazić sobie różnorodność projektów emancypacyjnych, które popierali emancypanci, lub tych, które (współ)tworzyli i o które walczyli emancypatorzy.

W opisywanym gronie znajdują się bracia (Leon Petrażycki, brat Jadwigi Petrażyckiej Tomickiej) lub mężowie (Hipolit Skimborowicz, mąż entuzjastki Anny z Sokołowskich; Jan Władysław Dawid, mąż Jadwigi Szczawińskiej; Stanisław Koszutski, mąż Ludwiki Jahołkowskiej; Odo Bujwid, mąż Kazimiery z domu Klimontowicz) emancypantek. Trudno jednak uznać, by postawa wymienionych zmieniała się właśnie lub tylko pod wpływem ich partnerek czy spokrewnionych z nimi kobiet walczących o własne prawa. Większość z emancypantów posiadała wyższe wykształcenie, miała szlacheckie pochodzenie, mieszkała w dużych aglomeracjach miejskich, a edukację wyższą odebrała na kilku uniwersytetach. Byli reprezentantami inteligencji. Nie oznacza to jednak, że wśród emancypantów nie znajdowali się inni mieszkańcy miast - rzemieślnicy, sprzedawcy, robotnicy, reprezentanci służby. Hipotetyczną grupę sojuszników rozszerzyć można także o mieszkańców wsi. W aspekcie klasowym, na tym etapie badań, niemożliwe staje się jednak wyjście poza hipotezę. W archiwach nie ma dokumentów potwierdzających działania reprezentantów wyżej wymienionych grup w badanym okresie. Założyć można również, że takie dokumenty, utrwalone relacje nigdy nie istniały.

Rysopis emancypantów skomplikować może wykorzystanie soczewki politycznej. W tym wypadku istotne staną się informacje dotyczące politycznych sympatii i przynależności emancypatorów. Wśród opisywanych mężczyzn znajdowali się demokratyczni liberałowie (Edward Prądzyński, Aleksander Świętochowski), socjaliści (Ludwik Krzywicki, Kazimierz Kelles-Krauz), narodowi demokraci (Eugeniusz Starczewski) czy konserwatyści (Jan Urban).

Wiele biogramów mężczyzn, których pisma badam, zawiera informacje o ich osadzeniu w więzieniach, odbywaniu kar za udział w protestach przeciw 
zaborczej władzy (Benedykt Dybowski, Józef Karol Potocki), za wzywanie do niesubordynacji wobec władzy (Leon Petrażycki), za przygotowanie tajnych kursów (Jan Władysław Dawid aresztowany i osadzony wraz z żoną Jadwigą Szczawińską) jako wynik oskarżenia o spisek (Edward Dembowski), o przygotowywanie powstania i szkodliwą patriotyczną działalność żony (Hipolit Skimborowicz), o udział w postaniu (Ignacy Junosza Drewnowski, Karol Lichtański) lub konspirację i próbę zamachu (Bronisław Piłsudski). Powyższy wykaz sugerować może przyległość postawy patriotycznej, propaństwowej i emancypacyjnej. Obrazuje ich suplementarność, nie przeciwieństwo. Nie oznacza to jednak, że związki emancypacji kobiet oraz interes narodowy lub państwowy zawsze szły w parze.

Wstępny rysopis emancypantów i emancypatorów obejmuje także ich profesje i funkcje. Wśród nich znajdowali się dziennikarze, publicyści, pisarze, wydawcy (Aleksander Świętochowski, Hipolit Skimborowicz, Adam Wiślicki, Józef Karol Potocki), redaktorzy, pedagodzy (Jan Władysław Dawid, Piotr Chmielowski), bibliotekarze (Edward Chwalewik), prawnicy (Karol Dunin, Józef Lange) wykładowcy uniwersyteccy (Piotr Chmielowski, Jan Baudouin de Courtenay), naukowcy: biolodzy (Benedykt Dybowski), socjologowie (Ludwik Krzywicki), chemicy (Bronisław Pawlewski), etnolodzy (Bronisław Piłsudski), bakteriolodzy (Odo Bujwid), prawnicy (Leon Petrażycki) lekarze (Włodzimierz Popiel, Walenty Łukasz Miklaszewski), działacze i twórcy systemów filozoficznych (Kazimierz Kelles-Krauz, Karol Lichtański).

Zajmowali różne funkcje i stanowiska. Wśród nich byli studenci (Stanisław Kijewski, Stanisław Karczewski), posłowie różnych parlamentów (Leon Petrażycki, Eugeniusz Starczewski) i profesorowie (Piotr Chmielowski, Napoleon Cybulski, Benedykt Dybowski, Jan Baudouin de Courtenay, Bronisław Pawlewski). Funkcje, które pełnili, okazywały się ważnym aspektem ich działań w sprawie równouprawnienia kobiet. Dosłownie informują nas o tym pisma Petrażyckiego i Bujwida. Obaj tematyzowali straty, jakie na polu zawodowym ponosili przez poparcie sprawy kobiet.

Wyposażeni w społeczny i kulturowy kapitał, w możliwości działania, wykształceni, mogli pozostawić ślady swojej działalności. Wśród nich znalazły się pisma udostępnione szerokiemu odbiorcy: odczyty, mowy, publicystyka prasowa, polemiki, publikacje popularnonaukowe, sprawozdania z podróży, z międzynarodowych kongresów i zjazdów kobiet, omówienia zapisów prawa, listy publiczne, manifesty i odezwy do mężczyzn oraz dokumenty prywatne, takie jak listy i pamiętniki. 


\section{Razem czy osobno?}

Ilustrując zbiorowe czy masowe działania mężczyzn wpierających emancypację Polek, wspomnieć należy o zawiązanej w 1913 roku Lidze Mężczyzn dla Obrony Praw Kobiet.

O stworzeniu Ligi dowiadujemy się z kart „Steru”. W zeszycie 19-20 za rok 1913 ukazał się tekst Liga mężczyzn do obrony praw kobiet. Ten obejmował informacje na temat samej ligi oraz tekst wystosowanej przez Ligę odezwy skierowanej do „wszelkiej kategorji organizacji i stowarzyszeń, tak męskich jak i kobiecych"9. Liga działała pod przewodnictwem prezydium, którego członkami byli Bronisław Pawlewski, Witold Lewicki i Ignacy Drewnowski. Z zapisów Romany Pachuckiej wiemy, że w jej szeregi zapisało się „40 przedstawicieli różnych stronnictw: ludowcy, postępowcy, socjalista, narodowi

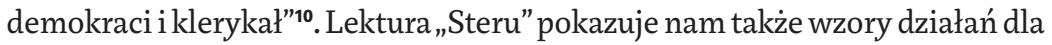
krajowych mężczyzn. W 9 zeszycie za 1907 rok znajdziemy informacje o Lidze mężczyzn działającej w Anglii"1", a we wspomnianym zeszycie z 1913 roku notę o zjeździe działającej od 1911 roku Międzynarodowej Ligii Mężczyzn.

Poza Ligą Mężczyzn do Obrony Praw Kobiet mężczyźni działali także w ramach organizacji kobiecych. Z zalegalizowanym w kwietniu 1907 roku Związkiem Równouprawnienia Kobiet kierowanym przez Paulinę Kuczalską-Reinschmit związani byli „ci z mężczyzn, którzy reprezentowali ideologię postępu społecznego"12. W tym samym czasie (legalizacja w lipcu 1907 roku) w zarządzie Polskiego Stowarzyszenia Równouprawnienia Kobiet obok siebie zasiadali kobiety i mężczyźni ${ }^{13}$. Członkiem zarządu był Stanisław Koszutski.

Sylwia Bujak-Boguska, charakteryzując PSRK, w rubryce Wspótpracowali wymieniła następujące nazwiska: „Ludwik Krzywicki, Stanisław Koszutski, W. Łypacewicza, Henryk Konic, Kurantowski, Popławski, Emil Rapaport, Sobolewski, Wacław Makowski, dr. Sterling, Kazimierz Stołyhwo, JózefWasowski, Stanisław Kempner"14. Z kolei z zapisów Jadwigi Petrażyckiej

9 [autor(ka) nieznany/a] Liga mężczyzn do obrony praw kobiet, „Ster” 1913 z. 19-20, s. 117.

10 R. Pachucka Pamiętnik z lat 1886-1914, wstęp i objaśnienia J. Hulewicz, Ossolineum, Wrocław 1958 , s. 273.

11 Liga mężczyzn dla wywalczenia praw wybiorczych kobiet w Anglii, "Ster” 1907 z. 9, s. 356-367. R. Pachucka Pamiętnik z lat 1886-1914, s. 93, przypis opracowany przez redaktora J. Hulewicza.

Tamże.

14 S. Bujak-Boguska Na straży praw kobiet. Pamiętnik Klubu Politycznego Kobiet Postępowych 1919-1939, Zakład Drukarski Jan Ulasiewicz i Syn, Warszawa 1930, s. 14. 
Tomickiej ${ }^{15}$, która zestawiła dane dotyczące Związku Równouprawnienia Kobiet we Lwowie, znamy liczbę członkiń i członków stowarzyszenia za lata 1909-1914. I tak, sprawozdanie za rok 1909/1910 wskazuje 200 członków, w tym 24 mężczyzn; sprawozdanie za rok 1910/1911: 238 członków, w tym 29 mężczyzn; sprawozdanie za rok 1911/1912: 345 członków, w tym 39 mężczyzn; sprawozdanie za rok 1912/1913: 400 członków, w tym 35 mężczyzn; sprawozdanie za rok 1913/1914: 446 członków, w tym 40 mężczyzn. Dwa ostatnie sprawozdania pokazują także mężczyzn tworzących Komisję rewizyjną ZRK: Bronisław Laskowski i Kazimierz Bogdanowicz. Prócz tego Petrażycka Tomicka wymieniła także mężczyzn biorących udział w wiecach i zabierających głos w dyskusji (16 maja 1914 roku) na temat reformy wyborczej.

Sprawozdania Petrażyckiej Tomickiej notują co roku około 10\% członków wpisanych na listę Związku Równouprawnienia Kobiet we Lwowie. Ich aktywność przejawiała się w czynnym udziale w wiecach i debatach. Podobnie w pozostałych organizacjach. Mężczyźni nie tylko byli w nich obecni, ale też czynni. Nie są to informacje rewolucjonizujące historię ruchu kobiet w Polsce. Z pewnością jednak są to informacje dotychczas niezbadane.

Wydaje się jednak, że samych działań opisywanych emancypantów i emancypatorów nie da się definiować za pomocą kategorii prokobiecego czy pro(-)feministycznego ruchu społecznego. Widzimy jedynie początki ruchu, który kształtować zaczął się dopiero przed wybuchem Wielkiej Wojny. Większość z badanych mężczyzn traktować można jako satelitów, ewentualnie członków kobiecych ruchów społecznych, nie jako przedstawicieli ruchów męskich.

Emancypanci i emancypatorzy rzadko zajmowali się opisem własnej pozycji. Ich pisma nie zawierają wątków osobistych czy autorefleksji. W ten sposób nie spełniają oni wymogów, jakie przed współcześnie działającymi feministami postawiła Alice Jardine. Nastawieni byli na współpracę ponad płciowym podziałem. To owocowało różnymi projektami. Mogło np. prowadzić do odpłciowienia obywatelek w trakcie ich uobywatelnienia, co wiązało się z mylnym ujęciem tego, co męskie, jako uniwersalne, obiektywne i pożądane, albo do oddania się pod przewodnictwo doskonalszych od mężczyzn kobiet.

15 Zwiq̨zek Równouprawnienia Kobiet we Lwowie. Przyczynek do Historii Równouprawnienia kobiet w Polsce, oprac. J. Petrażycka Tomicka, Gebethner i Wolff, Kraków 1931. 


\section{Osobne projekty wsparcia i wspólnotowe (?) motywacje}

Badając pisma i działania emancypatów i emancypatorów, poruszam się między 1842 i 1918 rokiem, między trzema epokami. Każda z nich zasilana była wpływem innych prądów intelektualnych, co znajduje odzwierciedlenie w tezach głoszonych przez emancypatorów. Zakresem badań obejmuję teren wszystkich trzech zaborów, co wiąże się z kontekstem różnych systemów prawnych, kwestiami gospodarczymi i możliwościami edukacyjnymi. Duże znaczenie dla kształtu popieranych reform mają także czynniki pochodzenia i klasy społecznej, którą reprezentują opisywani mężczyźni, ich poglądy polityczne oraz ugrupowania partyjne, z którymi się identyfikowali. Bardzo istotną kwestią jest także wprowadzanie w życie reform, które kolejno wywalczyły Polki. Ostatni aspekt nie oznacza jednak prostej zależności, wedle której większe możliwości działań wiązały się $\mathrm{z}$ żądaniem szerszych reform.

Dla przykładu wskazać można projekty Edwarda Prądzyńskiego i Eugeniusza Starczewskiego. Pierwszy zaprezentowany w 1873 roku był najpełniejszym, najbardziej przekrojowym omówieniem praw kobiet. Obejmował wszystkie zakresy reform: edukację, pracę, prawo rodzinne i prawa obywatelskie. Nie oznacza to jednak, że gwarantował kobietom pełną wolność i podmiotowość. Prądzyński chciał zapewnić kobietom pełnię praw, wymienił jednak czynnik, który ograniczać miał możliwość podejmowania przez kobiety samodzielnych kroków. Tym czynnikiem było małżeństwo. Jego podstawy Prądzyński osadził na kontrakcie dwóch stron, których równoznaczność w podejmowaniu rodzinnych decyzji prowadzić mogła do impasu. Wyjściem z patowej sytuacji było zróżnicowanie prawnych możliwości małżonków na rzecz bardziej doświadczonego społecznie i politycznie, czyli mężczyzny. To założenie prowadziło do paradoksu, w którym panna mająca pełnię praw traciła je na rzecz męża, z którym zawierała kontrakt oparty na właściwościach wynikających z płci kulturowej.

Książka Prądzyńskiego kończy się podsumowaniem, w którym autor w punktach odpowiedział na pytanie „czego kobieta ma prawo domagać się od prawodawcy, a czego od obyczajów?"16. W tym miejscu interesuje mnie tylko kwestia praw cywilnych. Tę obejmuje dopiero ósmy punkt wskazań autora. Liczebnik porządkowy wskazuje zakres pracy Prądzyńskiego.

E. Prądzyński O prawach kobiety, wydanie drugie uzupełnione, Nakładem księgarni Celsa Lewickiego i Sp., Warszawa 1875, s. nienumerowana. [spis treści za stroną tytułową, paginacja rozpoczyna się od pierwszej strony tekstu właściwego]. 
Po prawach dziewczyny, pracownicy, dziewicy, uwiedzionej, żony i matki Prądzyński wskazał prawa „kobiety wszystkich stanów i każdego położenia"17. Zagwarantował jej możliwość domagania się ludzkiej godności, dbania o własne zdolności i szeroki zakres wyboru pracy. Zdaniem Prądzyńskiego zniesione powinny zostać ograniczenia, które nie dopuszczały kobiet do uczestnictwa w radach familijnych. Autor postulował „wstęp do urzędów i godności dla wyjątków nie obarczonych rodziną a posiadających stwierdzone uzdolnienie; w szczególności zaś szeroki udział dla młodzieży niewieściej w zawiadywaniu miłosierdziem publicznym i nauczycielstwem ludowem"18 oraz prawo wyborcze „według ogólnych przepisów”"19.

Koncepcja Prądzyńskiego nie była uniwersalistyczna.W jego tekst wielokrotnie wpisane zostało założenie, wedle którego kobiecie jako człowiekowi należą się takie same prawa jakie ma bądź będzie miał mężczyzna. To założenie spełnia się w aspekcie prawa wyborczego. Jakiekolwiek czynniki zostaną weń wpisane, muszą obejmować kobiety i mężczyzn. Toteż perspektywa uniwersalistyczna może tu zostać podważona czynnikiem pochodzenia, wykształcenia czy posiadanego kapitału. Z repertuaru potencjalnych ograniczeń wyłączona została jedynie płeć.

Według założeń Prądzyńskiego tytuł i prawa obywatela dawało spełnienie obywatelskich powinności. Niestety tylko w przypadku mężczyzny. W przypadku kobiety, według obserwacji Prądzyńskiego, jej patriotyczna aktywność nie była nagradzana. Naród wymagał od niej społecznej solidarności i miłości do kraju, podobnie jak wymagał tego od mężczyzny. Nie zapewniał jej jednak żadnych praw. To miało być przyczyną niestałości jej uczuć wobec kraju oraz kosmopolitycznych zachcianek. Recepta była prosta:

Aby utrzymać kobietę w nierozerwalnym stosunku, jaki zachodzić powinien między społeczeństwem a składającemi je członkami, aby nastrój jej ducha do codziennych potrzeb narodu dostroić, aby, jednem słowem, umożebnić wypełnienie wszystkich jej względem kraju obowiązków, odpowiednie trzeba jej nadać obywatelskie prawa. ${ }^{20}$

17 Tamże, s. 313.

18 Tamże, s. 314.

19 Tamże.

20 Tamże, s. 220. 
Obowiązki kobiety wobec kraju spełniać mogły się w prowadzeniu i inspekcji szkół oraz nauczycielstwie, w zakładaniu ochronek, szkół specjalnych, bibliotek ludowych, w wypełnianiu (pośrednim lub bezpośrednim) prawa wyborczego. Słowem, kobieta powinna mieć możliwość wywierania wpływu na sprawy publiczne. Tylko wtedy zostanie „podporą i wspólniczką mężczyzny” 21. Odpowiadając na pytanie, jak daleko powinno się iść drogą emancypacji i do jakich stanowisk urzędowych kobiety dopuścić, Prądzyński twierdził, że wskazówką będzie doświadczenie, toteż:

rzeczą prawodawcy jest uprzystępnić dla kobiety wszystkie źródła nauki, z jakich dotąd tylko mężczyźnie wolno było korzystać, i znieść wszystkie zapory, jakie kobietę od urzędu odpychają; reszty dokona ona sama. Uzbrojona w rzeczywiste, faktami stwierdzone uzdolnienie i położone zasługi, wywalczy sobie co się jej słusznie należy, to mianowicie, w czem osiągnięte powodzenie, właściwe jej uzdolnienie wykaże. ${ }^{\mathbf{2 2}}$

Autor zbudował obraz otoczenia idealnego, w którym kobieta nie trafi na uprzedzenia i przeszkody niewynikające z prawnych uregulowań albo czynników ekonomicznych. Ten idealizacyjny aspekt miały podtrzymywać zapewnienia, wedle których kobieta emancypowana nie wkroczy w „atrybut mężczyzny"23. Ma się zbliżyć do biegu spraw publicznych, interesować nimi oraz zdobywać wykształcenie, co pozytywnie wpłynie na pełnioną przez nią rolę żony i matki. Wskazane role wynikać miały z powołania kobiety. Owo powołanie było zabezpieczeniem przed masowym wkroczeniem kobiet w sfery urzędnicze. Kariera urzędnicza wymagać miała „rutynicznego przygotowania”24, przez co „tylko przy wyjątkowem uzdolnieniu i o niektóre tylko urzędy kobieta dobijać się będzie, mianowicie o te, które wrodzonym jej skłonnościom odpowiadając, lepiej przez nią aniżeli przez mężczyznę sprawowane być mogą"25. Po zacytowanej uwadze, która służyć mogła pewnemu znormalizowaniu kwestii emancypacji kobiet, jak gdyby uspokojeniu odbiorców tekstu Prądzyńskiego, autor stwierdził, że o przyszłości nie możemy

\footnotetext{
21 Tamże, s. 223.

22 Tamże, s. 224.

23 Tamże, s. 220.

24 Tamże, s. 228.

25 Tamże.
} 
przesądzać, czym otworzył furtkę dla twierdzenia: nie wiadomo, co się stanie, więc nie zakładajmy najgorszego.

W innym miejscu, kilka akapitów przed zacytowanym sądem o możliwościach i uzdolnieniach kobiet, przytaczał przykłady sprawowania najwyższej godności w państwie przez kobiety. Na podstawie powyższych nie można jednak autorowi zarzucić braku logiki czy niekonsekwencji.Jego opinię na temat różnic między kobietami i mężczyznami budowało przekonanie o znacznym wpływie wychowania jednych i drugich na kształt ich psychiki. Poza tym, ponad płciową generalizacją stawiał różnice indywidualne: jak są mężczyźni z mniej lub więcej kobiecem usposobieniem, tak są kobiety z pewnemi właściwościami męzkiego temperamentu"26 - pisal.

Powtórzyć należy, że dla Prądzyńskiego kwestia praw ściśle wiązała się z kwestią obowiązków, toteż odpowiedź na pytanie o prawa dla kobiet za każdym razem zestawiona będzie z odpowiedzią na pytanie o to, czy i jakie kobieta ma mieć względem swojego kraju obowiązki. Reasumując, twierdził:

Przez nadanie kobiecie prawa wyborczego, przez zorganizowanie żeńskiej młodzieży w ochotnicze pułki pogromicielek niedoli ludzkiej i krzewicielek oświaty ludowej nie obalamy rodziny; wprowadzamy ją tylko jako ważny czynnik w organizm spółeczny, podnosimy jej znaczenie moralne, robimy z niej to, czem ona istotnie być winna w stosunku do społeczeństwa, to jest miejscem wyboru pojęć i bodźcem czynów obywatelskich. ${ }^{27}$

Kwestia doświadczenia i jego braku wpływać miała na podział kobiet na tzw. jednostki wyjątkowe, które dzięki reformom miały się spełniać zawodowo, urzędniczo, politycznie, oraz większość, która nie posiadała (jeszcze) właściwości i zdolności, by piastować funkcję urzędnika państwowego.

Przywołane założenie w 1916 i 1917 roku powtórzył Eugeniusz Starczewski. Pisma Starczewskiego ujawniają jego dyskusję z trzema projektami emancypacji zarysowanymi na łamach „Pokłosia Kobiecego”, dodatku do wydawanych w Kijowie „Kłosów Ukraińskich”. Autorkami owych projektów były Helena Pinińska, Amelia Grabowska i Ala Rosé-Drewnowska. Autor skłonił się wówczas do uobywatelnienia kobiet, zarysował też kilka wyjątków. Jednym z nich był zakaz pracy kobiet na stanowisku sędziów. Argumentował to faktem, że wskazana praktyka wymaga obiektywności i odrzucenia emocji,

26 Tamżey, s. 226.
27 Tamże, s. 250. 
co miało być trudne dla nieodpowiednio socjalizowanych i wykształconych kobiet.

Według publicysty pełnoprawnym obywatelem mogła być kobieta, która w przestrzeni publicznej wyzbyła się własnej płci. Nie ograniczały jej sprawy macierzyńskie i rodzicielskie, nie ograniczały jej także kwestie związane z systemem wychowania i kształcenia, czyli socjalizacją, która nie rozbudziła w niej zainteresowania kwestiami politycznymi. Zajmowanie politycznie istotnej roli wymagało od kobiety również odejścia od kierowania się czuciem.

Pełnoprawne obywatelstwo nie równało się więc uobywatelnieniu. Uobywatelniona kobieta poza możliwością a właściwie wymogiem pracy zarobkowej oraz rozwojowej, przede wszystkim egzystowała w sferze prywatnej jako partnerka, którą prawnie stać miała się jako żona oraz jako matka, która przejmowała władzę nad dziećmi lub dzieliła ją z ich ojcem. Niestety pełne polityczne równouprawnienie w oczach Starczewskiego równało się wspomnianej utracie płci. Taką drogę dla przyszłych polityków w odradzającej się Polsce rekomendował historyk, który wielokrotnie zwracał uwagę na kwestie źle pojmowanej wolności i dbania o indywidualne interesy, które wśród wielu innych problemów i powodów doprowadziły do upadku Polski.

Pełnia praw obywatelskich rozumiana jako „udział w sprawach publicznych"28 przysługiwałaby tym, które są na to gotowe. Inteligentnym, wykształconym, doświadczonym. Co nie oznacza, że owa grupa została przez Starczewskiego zamknięta.

Projekty emancypacji kreślone przez Prądzyńskiego i Starczewskiego dzielą 43 lata i szereg reform, o które walczyły kobiety (edukacja średnia, zawodowa, wyższa, możliwość pracy zawodowej, możliwość prowadzenia stowarzyszeń i zgromadzeń) oraz wybuch wojny światowej. Od 1897 roku Polki mogły zdobywać wykształcenie wyższe na akademiach działających w Galicji. To istotny czynnik, który mógł wpłynąć na socjalizację i wykształcenie kobiet. Dla Starczewskiego był on jednak mniej istotny niż jego troska o władzę i rządy projektowanego pod koniec Wielkiej Wojny niepodległego państwa. Jak widać, polityczny kontekst miał często kluczowe znaczenie dla popieranych przez emancypantów reform.

Dodatkowo, zestawiając pisma Prądzyńskiego i Starczewskiego, zaznaczyć należy, że omawiana powyżej wypowiedź Starczewskiego powstała 4 lata po

28 U. Frevert Mąż i niewiasta. Niewiasta i mąż. O różnicach płci w czasach nowoczesnych, przeł. A. Kopacki, Oficyna Wydawnicza „Volumen”, Warszawa 1997, s. 318. 
założeniu Ligi Mężczyzn do Obrony Praw Kobiet oraz 11 lat po tym, gdy Leon Petrażycki, współpracując z rosyjskim Związkiem Równouprawnienia Kobiet, postulował w I Dumie bezwarunkowe dopuszczenie kobiet do oświaty na wszystkich etapach edukacji oraz umożliwienie im zajmowania urzędów państwowych. Takie działanie miało zapewnić państwu stały dopływ oświeconych sił, które odpowiedzialne będą za wprowadzenie nowego ustroju. Przepis był jasny: im większy wybór wśród potencjalnych wykształconych pracowników, tym większa szansa na reformy ustrojowe i walkę z dotychczasowym systemem, który opierał się na nepotyzmie i dbaniu o własny interes. Swoboda wykształcenia i dostępu do pracy zapewnić miała napływ ludzi godnych i dzielnych, którzy pracować będą dla dobra powszechnego. „Wykluczenie całej połowy możebnych kandydatów - kobiet, byłoby bardzo niemądrym trwonieniem i bez tego niezasobnych sił"29, przekonywał Petrażycki.Z powyższego widać, że motywacja do zmian nie zakładała indywidualnych dążeń i interesów kobiet. Zmiana prawa miała przynieść obopólną wygraną, dla kobiet i dla społeczeństwa. Przy czym w wystąpieniu teoretyka prawa indywidualny interes pierwszych został niewypowiedziany. Ważniejsza pozostawała argumentacja kolektywna.

Głównym i najbardziej radykalnym punktem zakreślonego wniosku było przyznanie kobietom praw wyborczych w zakresie miejscowego samorządu i narodowego przedstawicielstwa.

Jest to punkt tego rodzaju, że bronić go wobec rozpowszechnionych przesądów jest to złożyć w ofierze opinję poważnego polityka, a nawet narazić się na szyderstwa. Tembardziej uważam sobie za obowiązek sumienia powiedzieć tu, że interes państwa, społeczeństwa i cywilizacji wymaga postawienia tego ostatniego, największego kroku - przyznania kobietom praw wyborczych. ${ }^{30}$

Powyższe zestawienie pism doskonale oświetla uskoki i różnice między kolejnymi projektami emancypacji Polek wspieranymi przez mężczyzn. Ich chronologia nie wiązała się z rozwojem liberalnej czy wolnościowej i równościowej myśli. Skontrastowane teksty Prądzyńskiego, Petrażyckiego i Starczewskiego przeczą teorii kuli śniegowej. Głoszone w nich idee mają związek

L. Petrażycki O prawa dla kobiet. Mowa wygłoszona w I Dumie rosyjskiej, przeł. J. Petrażycka Tomicka, Wydawnictwo Polskie, Lwów 1919, s. 9. 
z ówczesnymi, ważnymi dla nich kontekstami gospodarczymi i politycznymi. Prądzyński wspierał Polki, które muszą sobie samodzielnie radzić po ekonomicznych i rolniczych kryzysach pierwszej połowy XIX wieku, Petrażycki - głosem kobiet - przemawia właściwie w ogniu rewolucji 1905 roku, z kolei Starczewski tworzy swój projekt w kontekście realnych możliwości odrodzenia państwa i w chwili, gdy za chwilę wybuchnie rewolucja 1917 roku. Ostatnia zbieżność nie wspiera jednak siły i zakresu proponowanych reform.

Co istotne, rok po publikacji Starczewskiego, w 1918 roku na łamach jezuickiego „Przeglądu Powszechnego” ukazał się siedmioodcinkowy tekst księdza Jana Urbana, który odniósł się do kwestii praw obywatelskich dla kobiet. Uznał ją za jedno z ważniejszych i niedokończonych zagadnień XIX wieku. Niedokończonych, ponieważ z trzech głównych żądań kobiet: „chleba, wiedzy, pełni obywatelskich praw"31, wywalczono dwa pierwsze. Nieuniknione było rozwiązanie trzeciego żądania, szczególnie w „zmartwychwstającej Polsce"32.

W aspekcie wskazanych różnic istotna pozostaje motywacja autorów badanych tekstów. Refleksja, która obejmuje wskazanie roli, jaką w kwestii emancypacji kobiet odegrać mieli mężczyźni. W tym miejscu uwagę zwrócić należy na słowa Edwarda Prądzyńskiego, który na kartach $O$ prawach kobiety bezpośrednio zwracał się do mężczyzn:

Młodzieńcze, mężu i ojcze! Kobieta, uroczy przedmiot namiętnych hołdów a samolubnego władztwa twojego, dziś upomina się o człowieczeństwo swoje; berło myśli i pracy z tobą dzielić pragnie. Dziejowy rozwój społeczeństwa stanął już po jej stronie i bezsprzeczny jej w tych usiłowaniach gotuje tryumf. Złowrogie głosy zgubny w tem zapowiadają przewrót i w fantastycznem widmie kobiety-emancypantki już widzą osieroconą rodzinę, zszarganą godność niewiasty. Mężczyzno! W twojem ręku. Jeżeli twe serce umiłowało to, co prawdziwie piękne i szlachetne, nie rzucaj bezsilnego przekleństwa na nieunikniony postęp ludzkości. Rodzina zagrożona! a więc wesprzyj ją męzką siłą! staraj się zbliżyć do kobiety potęgą i czystością uczuć, odwróć się od zwodniczych zmysłowych uciech: ukochaj domowe ognisko, otocz czcią należną święty węzeł małżeński i nie szukaj w nim tylko wypoczynku dla przekwitłej młodości, pożądanej areny dla rozpanoszonej męzkiej dumy i tradycyjnie

31 J. Urban O prawa obywatelskie dla kobiet, "Przegląd Powszechny” 1918, s. 276-293, 414-431.

32 Tamże, s. 276. 
zaszczepionego samolubstwa; ale uczyń zeń raczej społeczność prawdziwą, związek dwóch równych i jednako uprawnionych istot, zdwajający siły jednostki, czyniący z rodziny przybytek życiowej wiedzy, szkołę uczuć, moralności i obywatelstwa, niewyczerpane źródło wzniosłych rozkoszy ... a po tem wszystkim bądź pewny, że towarzyszki twojej, wyniesionej na wyższy szczebel życia, nie olśnią błyskotliwe utopie, że nie zamieni ona czarownej harmonii dusz waszych, na bezmyślny gwar uliczny, że nie poświęci obowiązków rodzinnych dla czczych urojeń próżności!33

Zacytowany akapit oddaje paradoks książki Prądzyńskiego. Autor dostrzegał potrzebę zmian pozycji kobiet, ale nie postulował zmiany ich roli. Zakładał też współpracę kobiet i mężczyzn oraz zmianę motywacji i zachowań tych ostatnich. Jednocześnie projekt emancypacji fizycznej, umysłowej i moralnej przedstawiał jako działania osobne, niezależne od utopii, która odciągała kobiety od ich zadań. Nadal to mężczyzna miał czuwać nad szlachetnością i pięknem kobiety, gwarantować jej moralność i obywatelstwo.

Inny z badanych z autorów, Stanisław Koszutski, pisał następująco:

Nad zbliżeniem tej chwili pracować winny w interesie własnym i kultury - kobiety, w interesie sprawiedliwości i dla zmazania z siebie ciężkiej winy odwiecznego poddaństwa kobiet - wszyscy czujący i myślący mężczyźni. ${ }^{34}$

Opisywana chwila to równe i powszechne prawa wyborcze, dzięki którym zniknie „walka o przywileje dla mężczyzn lub o prawa dla kobiet, a miejsce jej zajmie wspólna praca nad budowaniem lepszego jutra ludzkości"35.W tym akapicie autor ujął podwójny interes - indywidualny i wspólnotowy. Wskazał także odpowiedzialność i winę mężczyzn.

Stanisław Kijewski, relacjonując I-szy Wszechrosyjski zjazd w sprawie tzw. handlu żywym towarem w Petersburg, donosił:

adwokat W. de Planson scharakteryzował 10-letnią działalność Tow. ochrony kobiet. Jedną z przyczyn słabego rozwoju Towarzystwa widzi

33 E. Prądzyński O prawach kobiety, s. 172.

S. Koszutski Kobieta i polityka, Polskie Stowarzyszenie Równouprawnienia Kobiet, Skład główny księgarni Gebethnera i Wolfa, Warszawa 1908, s. 30.

Tamże. 
referent w odnoszeniu się mężczyzny do tej sprawy.„,Męska połowa społeczeństwa - powiada de Planson - sama przeszła przez szkołę prostytucji, sama została zbrukaną przez jej demoralizujące wpływy i obecnie jeżeli nie przeszkadza, to milczy lub omija tę bolączkę społeczną. ${ }^{36}$

W tym cytacie także odpowiedzialność splata się z winą mężczyzn, którzy zostali zbrukani łatwym dostępem do usług seksualnych i na różne sposoby podtrzymują zastany porządek społeczny, zamiast wspólnie walczyć z wykorzystywaniem kobiet.

W innym miejscu Kijewski pisał:

I słusznie już ktoś wyrzekł, że instytucje nasze i prawa takie będą, jacy i my sami będziemy. Od nas mężczyzn musi się rozpocząć reforma, żadne prawa, żadne przepisy nie zwalczą tego zła, które swe źródło ma w nas samych. ${ }^{37}$

Wskazane cytaty odnoszą się do różnych kwestii. Pierwszy do zrównania praw politycznych, dwa następne dotyczą walki z seksualnym wykorzystywaniem kobiet. Wszystkie wskazują odpowiedzialność i potrzebę aktywności mężczyzn. Motywacją do działania miało być odkupienie własnych win i walka o sprawiedliwość.

Najsilniej winę i odpowiedzialność mężczyzn akcentował Stanisław Karczewski w drukowanej na łamach „Steru” odezwie Zbudźmy się do czynu!. Podmiotem tekstu Karczewskiego była zbiorowość, autor pisał „my”.W to miejsce w poszczególnych fragmentach tekstu podstawić można mężczyzn lub całe społeczeństwo. Ta kwestia nie zostanie rozstrzygnięta. Niektóre jednoznacznie odnoszą się do działań męskich oprawców, inne można generalizować poza płcią. Ważny pozostaje fakt, że obie interpretacje podmiotu niniejszej odezwy obejmują mężczyzn.

W tekście pojawiają się retoryczne pytania i zarzuty:

Czy nie my stworzyliśmy zło? Czy nie pchamy kobiety do spełnienia takiego okrutnego czynu? [zabójstwa dziecka - przyp. M.D.] ${ }^{38}$

36 S. Kijewski Walka z prostytucja , "Ster" 1910 z. 5, s. 230.

37 S. Kijewski Zżycia współczesnej niewolnicy, "Ster” 1910 z. 11/12, s. 264.

38 S. Karczewski Zbudźmy się do czynu!, „Ster” 1909 z. 5, S. 173. 
Jesteśmy mądrzy i przebiegli! Stworzyliśmy dwie „moralności”; jedną dla siebie, jako istot „wyższych” a drugą dla kobiet. ${ }^{39}$

Pozakładaliśmy osobne uczelnie, w których systematycznie staramy się skuć ich mózgi i wytresować dusze, bo przecież kobiecie nic nie wypada. ${ }^{40}$

Stworzyliśmy całe legiony lalek, kokietek i modnych kobiet, pchnęliśmy mnóstwo w przepaść brudu! 41

Skutkiem tej samokrytyki stało się wezwanie do opamiętania, do docenienia treści, a nie pustych form oraz do walki o wyzwolenie kobiety:

Ukochajmy w kobiecie nie żonę tylko, lecz towarzyszkę i przyjaciółkę życia, matkę i wychowawczynię przyszłych pokoleń, kapłankę najwyższą domowego ogniska, twórczynię ciepła rodzinnego.

Ukochajmy w kobiecie człowieka, ukochajmy jej duszę!

Lecz aby kobieta mogła spełniać dobrze swe zadanie, do którego jest powołaną przez miłość - musi być wyzwoloną z pęt. Dążmy do wyzwolenia kobiet! Dążmy, jeśli nie chcemy zupełnie się pogrążyć w bagnie i brudach życiowych. Dążmy do wyzwolenia kobiet, bo przez wyzwolenie kobiety przyjdzie wyzwolenie całego społeczeństwa!42

Najpowszechniejsza wśród opisywanych działań wydaje się motywacja zakładająca wspólny interes społeczny. Sojusz zawarty ponad płciami. Sojusz, który owocować miał rozwojem obywatelskiej świadomości córek i synów ojczyzny, ich pracą na rzecz odzyskania niepodległości a później staraniem o jak najlepszy kształt odradzającego się państwa. Ta argumentacja nie uwzględniała kwestii winy, a odpowiedzialność wiązała z dbałością o państwo i naród, czyli o mających obowiązki obywateli i obywatelki, nie o mających prawa mężczyzn i kobiety. Poniżej przywołam dwa reprezentatywne cytaty. Pierwszy z mowy Petrażyckiego:

\footnotetext{
39 Tamże, s. 170.

40 Tamże.

41 Tamże, s. 171.

42 Tamże.
} 
Interes dobra ogółu i kultury wymaga, abyśmy przyznali kobietom prawa polityczne, tj. prawa i obowiązki społeczne. ${ }^{43}$

i drugi z artykułu Urbana:

Nawzajem, popierając dążenia kobiece, nie działamy dla jakiejś wrogiej nam, mężczyznom, klasy gdyż działamy w interesie naszych matek, żon, sióstr i córek. Podnosząc je, podnosimy samych siebie w nich.

Przemawiając tedy za równouprawnieniem obywatelskiem kobiet, nie przemawiamy w imię jakiegoś ich wyłącznego interesu, przeciwstawionego interesom mężczyzn, ale w imię wspólnego dobra wszystkich. W równouprawnieniu kobiet dokona się wykończenie dzieła demokratyzacyi społeczeństw. ${ }^{44}$

Odpowiedź na pytanie dotyczące motywacji mężczyzn wspierających emancypację kobiet nie jest jednoznaczna i stosunkowo rzadko odnosi się do postulatów zawartych w ideach ruchu feministycznego. Sojusz z kobietami działał na korzyść obywateli, narodu, państwa. Zgodny był z oświeceniowymi ideałami, demokratycznymi założeniami, postulatem powszechnej sprawiedliwości społecznej. Kwestia indywidualnego interesu kobiet wybrzmiewała w drugim planie albo w kontekście zmian gospodarczych. Autorefleksyjny głos mężczyzn, biorących odpowiedzialność za społeczną pozycję kobiet, silnie wybrzmiał dopiero w momencie dyskusji reform obyczajowych.

Odpowiedź na pytanie o motywacje emancypantów może być także odpowiedzią na pytanie o to, co zyskiwali i co tracili mężczyźni współpracujący z emancypantkami i kobiecymi organizacjami. Po stronie zysków znajdowało się projektowane, niepodległe państwo, spełnienie demokratycznych ideałów oraz możliwość odkupienia win. Po stronie strat przyznanie się do winy, utrata przywileju i pozycji oraz prasowe ataki na mężczyzn wspierających kobiety.

43 L. Petrażycki O prawa dla kobiet, s. 13.

44 J. Urban O prawa obywatelskie dla kobiet, s. 430. 


\section{Abstract}

\section{Maciej Duda}

THE JACOB OF PARADIES UNIVERSITY

Solidarity beyond Gender (?): Men's Support in the Struggle for Polish Women's Suffrage

Duda presents an aspect of his research on men who supported the emancipation of Polish women at the turn of the twentieth century. He discusses writers who called for universal and equal voting rights for both sexes, highlighting Edward Prądzyński's book as well as journalistic writing by Eugeniusz Starczewski and Jan Urban. A key event is Leon Petrażycki's speech to the First Duma in 1906. Petrażycki, a university professor and delegate, headed a sub-commission on women's rights, and he worked with the Związek Równouprawnienia Kobiet (Union for the Equal Rights of Polish Women) in Saint Petersburg. His speech was translated into Polish, French, Italian, English and German. This episode of the First Duma is a key example of men's efforts to support the voting rights reforms that were composed and declared following the 1905 Russian Revolution.

\section{Keywords}

women's emancipation, women's rights, men, emancipators 